\title{
Etilefrine Pivalate
}

National Cancer Institute

\section{Source}

National Cancer Institute. Etilefrine Pivalate. NCI Thesaurus. Code C65577.

A prodrug of etilefrine, an adrenergic agonist with vasoconstrictive activity. Etilefrine pivalate is hydrolyzed to etilefrine, which binds to and activates alpha-1-adrenergic receptors of the arteriolar and venous vasculature. This causes smooth muscle contraction and leads to a decrease in venous pooling and increase in blood pressure. This agent may also stimulate beta-1 adrenergic receptors leading to positive chronotropic and inotropic effects. 